\title{
DISCUSSION.
}

\section{THE SEXUAL ELEMENT IN SENSIBILITY.}

Any theory of socialization must give first-rate importance to the influence on the individual of the presence, behavior and opinion of others; and the quality of suggestibility to social influence, so important in the formation of the character of the individual and in the formation of society itself, seems to have two sources, one in the food process and the other in the process of reproduction.

The life of any highly organized species depends on the quickness, precision and adequacy of its reaction to stimuli. New and dangerous or advantageous situations are constantly presenting themselves and the species develops both the cognition and the emotional reactions suitable to accommodate to these. Every such species has, in consequence, a high degree of susceptibility. Perhaps the most remarkable expression of susceptibility in the human species is seen in the sensitiveness of man to the opinion in which he is held by others. Social life in every stage of society is characterized by an eagerness to make a striking effect. A bare reference to the ethnological facts in this connection will suffice: The Kite Indians have a society of young men so brave and so ostentatious of their bravery that they will not fight from cover nor turn aside to avoid running into an ambuscade or a hole in the ice. The African has the privilege of cutting a gash six inches long in his thigh for every man he has killed. The Melanesian who is planning revenge sets up a stick or stone where it can be seen; he refuses to eat, and stays away from the dance; he sits silent in the council and answers questions by whistling, and by other signs draws attention to himself and has it understood that he is a brave and dangerous man, and that he is biding his time.

This bidding for the good opinion of others has plainly a connection with food-getting, and with the conflict side of life. High courage is praised and valued by society, and a man of courage is less imposed on by others and comes in for substantial recognition and the favor of women. It is thus of advantage to act in such a way as to get public approval and some degree of appreciation: and a degree of sensibility on the score of the opinion of others, or at least a reckoning upon this, is involved in the process of personal adjustment. 
But the problem of personal adjustment at this point would seem to call for more of intelligence than emotion; and we find, on the contrary, an excess of sensibility and a mania for being well thought of hardly to be explained as originating in the exigencies of tribal organization, nor yet on the score of its service to the individual in getting his food and living out his life. Why could not primitive man live in society, be of the war-parties, plan ambuscades, develop his fighting technique and gear, be a blood-brother to another man, show his trophies, set a high value on his personality and insist on recognition and respect, without this almost pathological dependence on the praise and blame of others?

Or if we approach the question from another standpoint and inspect our states of consciousness, we find signs that we have a greater fund of sensibility than is justified in immediate activity. We have the same mania to be well thought of ; we are unduly interested when we hear that others have been talking about us, we are annoyed, even furious, at a slight criticism, and are childishly delighted by a compliment (without regard to our deserts); and children and adults alike understand how to put themselves forward and get notice, and equally well how to get notice by withdrawing themselves and staying away or out of a game. We have a tendency to show off which is not apparently genetically connected with exploit or organization, and we recognize that this form of vanity is not consistent with the ordinary run of our activities when we argue with ourselves that the opinion of this or that person is of no consequence and attempt to think ourselves into a state of indifference. Intellectually and deliberately our attitude toward criticism from others would often be, if we could choose, represented by Tweed's query, 'What are you going to do about it?' but actually it puts us to bed.

All of this seems to indicate that there is an element in sensibility not accounted for on the exploit or food side, and this element is, I believe, genetically connected with sexual life. Unlike the struggle for existence in the ordinary sense of the phrase, the courtship of the sexes presents a situation in which an appeal is made for the favor of another personality, and the success of this appeal has a survival value - not for the individual, but for the species through the individual. We have, in fact, a situation in which the good opinion of another is vitally important. On this account the means of attracting and interesting others are definitely and bountifully developed among all the higher species of animals. Voice, plumage, color, odor and movement are powerful excitants in wooing and aids both to the con- 
quest of the female and the attraction of the male. In this connection we must also recognize the fact that reproductive life must be connected with violent stimulation, or it would be neglected and the species would become extinct; and, on the other hand, if the conquest of the female were too easy, sexual life would be in danger of becoming a play interest and a dissipation, destructive of energy and fatal to the species. Working, we may assume, by a process of selection and survival, nature has both secured and safeguarded reproduction. The female will not submit to seizure except in a high state of nervous excitation (as is seen especially well in the wooing of birds), while the male must conduct himself in such a way as to manipulate the female; and, as the more active agent, he develops a marvelous display of technique for this purpose. This is offset by the coyness and coquetry of the female, by which she equally attracts and fascinates the male and practices upon him to induce a corresponding state of nervous excitation. ${ }^{1}$ This is the only situation in the life of the lower animals, at any rate, where the choice of another is vitally important; and corresponding with the elaborate technique to secure this choice we have in wooing pleasure-pain reactions of a violent character. In a word, extreme sensitiveness to the judgment of another answers on the subjective side to technique for the conquest of a member of the opposite sex. It seems, therefore, that we are justified in concluding that our vanity and susceptibility have their origin largely in sexual life, and that, in particular, our susceptibility to the opinion of others and our dependence on their good will are genetically referable to sexual life.

This view would be completely substantiated if we could show that the qualities of vanity and susceptibility in question are present in any species where it is impossible to assume that they were developed in connection with the struggle for food and as the result of the survival of types showing a tendency to combine and cooperate in the effort to get food. And we do, in fact, have cases of this kind among some of the lower animals. It cannot be said that the dog, for instance, has survived in the struggle for existence because of his sensitiveness to public opinion in his species nor on account of an interest in being well thought of by the community of dogs at large which would lead him to behave in a public-spirited or moral manner. At the same time, the dog in his relation to man shows as keen a sensitiveness to man's opinion and treatment as does man himself. The attention which the master pays to one dog will almost break the heart of a dog not receiving it. A neglected dog plainly suffers as much in

${ }^{1}$ See Groos, The Play of Animals, p. 283. 
his way as the soldier who is sent to Coventry by his messmates; and if neglected and jealous dogs do not commit suicide, as they are reported to do, they are evidently in a state of mind to do so. This means that the dog has highly developed susceptibility to the appreciation of others, and that the species which he represents has had no history except a sexual history capable of developing this inental attitude. In connection with courtship he developed a fund of organic susceptibility, and this condition is involved in his more general relation to man: the machinery set up in sexual relations is played on by stimuli in general. A condition favorable to stimuli of a particular kind is favorable to stimuli in general; and it seems likely that this not very prominent fact of a state of excitation in a sexual connection is an important factor in the formation of the mind and of society.

There are also certain conditions in the development of the individual and of society where the sexual type of reaction is so near the surface that it shows through in connection with political, moral and other essentially non-sexual activities. Passing over the fact that the period of adolescence is noticeably a period of 'susceptibility' and personal vanity, we may take as an example of the intrusion or persistence of the sexual element in conditions of a non-sexual kind the frequent association of sexual with religious excitement. ${ }^{1}$ The appeal made during a religious revival to an unconverted person has psychologically some resemblance to the attempt of the male to overcome the hesitancy of the female. In each case the will has to be set aside, and strong suggestive means are used; and in both cases the appeal is not of the conflict type, but of an intimate, sympathetic and pleading kind. In the effort to make a moral adjustment it consequently turns out that a technique is used which was derived originally from sexual life, and the use, so to speak, of the sexual machinery for a moral adjustment involves, in some cases, the carrying over into the general process of some sexual manifestations. The emotional forms used and the emotional states aroused are not entirely stripped of their sexual content. On the race side, also, there is a stage in development where the sexual pattern is transferred almost unmodified to public affairs. The following extracts from a lengthy description given by Mr. Bowdich of his reception by the king of Ashanti, in the year $\mathrm{s}_{17}$, will illustrate sufficiently the employment of the turkey-cock pattern of activity in political relations :

'See e. g., Kraft-Ebing, Pychopathia Sexualis, 3 Aufl, p. I0; Adams, 'Some Phases of Serual Morality and Church Discipline in Colonial New England,' Proceedings of the Mass. Hist. Soc., ad Series, I891, pp. 417-516. 
"The sun was reflected with a glare scarcely more supportable than the heat from massive gold ornaments which glistened in every direction. More then a hundred bands burst at once on our arrival, with the peculiar airs of their several chiefs; the horns flourished their defiances, with the beating of innumerable drums and metal instruments, and then yielded for a while to the soft breathings of their long flutes. - At least a hundred large umbrellas or canopies, which could shelter thirty persons, were sprung up and down by the bearers with brilliant effect, being made of scarlet, yellow, and the most showy cloths and silks, and crowned on the top with crescents, pelicans, elephants, barrels, and arms and swords of gold. * The caboceers, as did their superior officers and attendants, wore Ashanti cloths of extravagant price, from the costly foreign silks which had been unravelled to weave them in all the varieties of color as well as pattern; they were of incredible size and weight, and thrown over the shoulder exactly like the Roman toga ; a small silk fillet generally encircled their temples, and many gold necklaces, intricately wrought, suspended Moorish charms, dearly purchased, and enclosed in small square cases of gold, silver and curious embroidery. Some wore necklaces reaching to the waist, entirely of aggry beads; a band of gold and beads encircled the knee, from which several strings of the same depended; small circlets of gold, like guineas, rings and casts of animals were strung round their ankles; their sandals were of green, red, and delicate white leather; manillas, and rude lumps of rock gold hung from their left wrists, which were so heavily laden as to be supported on the head of one of their handsomest boys. - - [The king] wore a fillet of aggry beads round his temples, a necklace of gold cockspur shells strung by their larger ends, and over his right shoulder a red silk cord, suspending three sapphires cased in gold; his bracelets were of the richest mixtures of beads and gold, and his fingers covered with rings; his cloth was of a dark green silk, a pointed diadem was elegantly painted in white on his forehead; also a pattern resembling an epaulette on each shoulder, and an ornament like a full blown rose, one leaf rising above another until it covered his whole breast. * - The belts of the guards behind his chair were cased in gold, and covered with small jaw-bones of the same metal; the elephants' tails, waving like a small cloud before him, were spangled with gold, and large plumes of feathers were flourished among them. His eunuch presided over these attendants, wearing only one massive piece of gold about his neck; the royal stool, entirely cased in gold was displayed under a splendid umbrella, with drums, sankos, horns, 
and various musical instruments, cased in gold, about the thickness of cartridge paper; large circles of gold hung by scarlet cloth from the swords of state; * hatchets of the same were intermixed with them; the breasts of the Ochras and various attendants were adorned with large stars, stools, crescents, and gossamer wings of solid gold***" 1

It is not surprising that the characteristically sexual method of display and emotional appeal should be associated with the earlier efforts at adjustment, both in the individual and in the state. This method is based on the instincts, and just as inhibition and brain integration follow the instincts in point ofdevelopment, a rational mode of control, individual and public, is developed later than the emotional form, or, at any rate, is not at first independent of it.

The origin of mental impressionability seems to lie then not in one but in the two general regions of activity - that connected with the struggle for food and that connected with reproduction. The strain on the attention in the food and conflict side of life involves the development of mental impressionability, particularly of an impressionability on the side of cognition. But in addition we have the impressionability growing out of sexual life which has been in question above, and which is more closely related to appreciation than to cognition. And of these two aspects of impressionability - the one growing out of contlict and the one growing out of reproduction, the latter has more social possibilities than the former, because it implies a sympathetic rather than an antagonistic organic attitude. It is certainly in virtue of susceptibility to the opinion of others that society works - through public opinion, fashion, tradition, reproof, encouragement, precept and doctrine - to bring the individual under control and make him a member of society; and it is doubtful whether this could have been accomplished if a peculiar attitude of responsiveness to opinion had not arisen in sexual relations, reinforcing the more general and cognitive impressionability. Without this capacity to be influenced the individual would be in the condition of the hardened criminal, and society would be impossible.

This sex-susceptibility which was originally developed as an accessory of reproduction and had no social meaning whatever, has thus, in the struggle of society to obtain a hold on the individual, become a social factor of great importance and together with another product at sexual life - the love of offspring - it is, I suspect, the most immediate source of our sympathetic attitudes in general, and an important

${ }^{1}$ Ellis, The Tshi-speaking Peoples of the Gold Coast, p. $249 \mathrm{ff}$. 
force in the development of the ideal, moral and æsthetic sides of life. It is perhaps not pushing the matter too far to suggest also that the duality of motivation which characterizes our social system, and which we designate as egoism on the one hand and altruism on the other, is a natural result of the contrast in character between the states of consciousness originating in the struggle for food and those originating in courtship, and that the history of society on the moral and æsthetic sides is in great part the history of an attempt to make the more sym. pathetic attitude prevail over the more antagonistic.

The University of Chicago.

W. I. Thомas.

\section{DR. MORTON PRINCE AND PANPSYCHISM.}

In the last number of this Review- Dr. Morton Prince points out that the panpsychist doctrine of my Why the Mind has a Body was anticipated in his Nature of MIind and Human Automatism published in $\mathrm{ISS}_{5}$. The interesting quotations which he makes from the latter and from an article in Brain for 1891 certainly bear him out in this assertion. With the book I regret to say that I was unacquainted. But I read his article some ten years ago, and I think that it contributed to turn my thoughts in a panpsychist direction. Its clear teaching that consciousness is the reality which appears as the brain-process helped to fix that hypothesis in my mind, and I have no doubt that the pages of Paulsen, ${ }^{1}$ to which I have always felt myself mainly indebted, had a fuller meaning to me in consequence. I regret the more that, by the time when I came to write, my memory of its contents had lapsed, and I failed, rather inexcusably it now seems to me, to mention $\mathrm{Dr}$. Prince among earlier expositors of the theory. Had I been acquainted with his book, I should have had a juster appreciation of his merits as a pioneer of panpsychism, and this would not have happened.

I have lately had the pleasure of reading the book, and I find that it contains an extremely clear and forcible statement of the panpsychist hypothesis. It differs from Clifford's essay on the 'Nature of Things-in-Themselves' in being not merely an exposition of panpsychism in the abstract, but a definite application of it to the problem of the connection of mind and body. ${ }^{2}$ Readers who have difficulty in $38 \mathrm{I}-85$.

1 Einleilung in die Philosophie (1892), see esp. pp. 77-116, 137-149,

2Towards the close of his essay on Body and Mind Clifford does make a rather definite application of it to the problem, as is shown by the sentence: "If mind is the reality or substance of that which appears to us as brain-rction * * *" (Lectures and Essays, 2d ed., p. 269). 